\title{
亜すす酸ナトリウム添加浴からの無電解ニケッル- すずーりん合金めっきについて
}

\author{
青 木 公二*・鷹 野
Electroless Nickel-Tin-Phosphorus Alloy Plating from Baths Containing Sodium Stannite

修*

Koji AOKI* and Osamu TAKANO*

\begin{abstract}
A study of electroless nickel-tin-phosphorus alloy plating from ammonia alkaline citrate bath (A-C bath) and from caustic alkaline citrate bath ( $\mathrm{C}-\mathrm{C}$ bath) containing sodium stannite has been made with reference to the effect of the tin content on deposition condition and the corrosion behavior of the alloy. It was found that the deposition rate increased with increasing amount of sodium stannite in A-C bath, but this effect was very small in $\mathrm{C}-\mathrm{C}$ bath. The tin content in the deposits increased up to $19.2 \%$ in A-C bath and $12.4 \%$ in C-C bath. In a $0.5 \mathrm{M}$ sulfuric acid solution at $30^{\circ} \mathrm{C}$, however, the tin cotent in the deposits from A-C bath increased about more than $7 \%$ and that from $\mathrm{C}-\mathrm{C}$ bath increased more than $12 \%$. Severe corrosion of the alloy in the solution is due to the formation of metastable phase $\mathrm{Ni}_{3} \mathrm{Sn}_{4}$. The corrosion resistance of the depeposits, containing $2.8 \%$ tin and $4.4 \%$ phosphorus, from $\mathrm{A}-\mathrm{C}$ bath, and of the deposits containing $8.4 \%$ tin and $8.3 \%$ phosphorus, from $\mathrm{C}-\mathrm{C}$ bath was excellent.
\end{abstract}

\section{1. 緒 言}

電着ニッケルーすず合金めっきではすずが $65 \%$ 含有す る皮膜が得られることが知られて括り ${ }^{1), 2)}$ ，またすずを $20 \%$ 含有するニッケルーすず合金めっきがヒドラジン還 元による 無電解めっさで得られるという報告もある3)。 これらの合金めっき皮膜はいずれも耐食性に優れてい る。一方，次亜りん酸塩還元による無電解ニッケルめっ き皮膜は数\%から十数\%のりんを含有し，りん含量の多 いものほど耐食性は良いといわれる。著者らは無電解二 ッケルめっき皮膜中にすずを含有させることにより，さ らに耐食性の良い皮膜を得ることを目的として酸性浴ま たはアンモニアアルカリ性浴について検討し，この目的 をある程度達成するニッケルーすずーりん合金めっきが得 られる浴条件を既に報告した ${ }^{4), 5) 。 し か し な か ゙ ら こ れ ら ~}$ の皮膜では最高 1 〜 \% 程度のすずを含有させるに止ま り，より高すず含有皮膜を得られる浴の出現が望をれて いた。本研究は亜すす酸塩を使用した無電解ニッケルー すずーりん合金めっき浴について検討した結果，前記の 浴に比へはるかに高すず含有皮膜の得られる浴条件を決 定した。さらに得られた皮膜の希薄硫酸に対する溶解

* 姫路工業大学（开671-22 姫路市書写2167）

Himeji Institute of Technology (2167, Syosya,

Himeji 671-22)
特性についても検討したので以下にその詳細を報告す る。

\section{2. 実 験 方 法}

\section{2-1 めっき浴の選定}

めっき浴には表 1 亿示すような亜すず酸ナトリウム注) を含むアンモニアアルカリ性クエン酸浴（A-C浴と略

Table 1 Basic bath compositions and plating conditions

\begin{tabular}{c|c|c}
\hline \hline Bath & A-C & C-C \\
\hline $\mathrm{NiCl}_{2}$ & 0.1 & 0.1 \\
\hline $\mathrm{NaH}_{2} \mathrm{PO}_{2}$ & 0.2 & 0.2 \\
\hline $\mathrm{Na}_{2} \mathrm{SnO}_{2}$ & 0.004 & 0.003 \\
\hline $\mathrm{Na}^{-\mathrm{Cit}}$ & 0.12 & 0.12 \\
\hline $\begin{array}{c}\mathrm{pH} \\
\text { bath temp. } \\
\begin{array}{c}\text { volume/area)ratio } \\
\text { plating time }\end{array}\end{array}$ & $\begin{array}{c}\text { with } \mathrm{NH}_{4} \mathrm{OH} \text { with } \mathrm{NaOH} \\
90^{\circ} \mathrm{C} \pm 1^{\circ} \mathrm{C} \\
200 \mathrm{~cm}^{3} / 10 \mathrm{~cm}^{2} \\
10 \mathrm{~min} .\end{array}$ \\
\hline \hline
\end{tabular}

注) $\mathrm{Na}_{2} \mathrm{SnO}_{2}$ の作成方法; $\mathrm{SnCl}_{2}$ 溶液飞 $\mathrm{NaOH}$ 溶夜 を滴下し，最初に生じた白沈が溶けて透明になったとこ ろで止め, 沪過後使用した。この溶液は長く放置すると 加水分解を起こすため, 実験直前に作成した。反応式は 次のと打りである。

$\mathrm{SnCl}_{2}+4 \mathrm{NaOH} \rightarrow \mathrm{Na}_{2} \mathrm{SnO}_{2}+2 \mathrm{NaCl}+\mathrm{H}_{2} \mathrm{O}$ 
す）とカセイアルカリ性クェン酸浴（C-C浴と略す）の 二種の基本浴で, 浴成分濃度及び条件を変化させて浴の 安定性, 析出速度, 皮膜の表面状態及びすず含量, りん 含量に及ぼす影響を調べその好適浴条件を決定した。な 扰析出速度は素地銅板 $10 \mathrm{~cm}^{2}$ あたり 10 分 間の析出重量 （mg）で表わした。浴温はすべて $90^{\circ} \mathrm{C} \pm 1{ }^{\circ} \mathrm{C} て ゙$ 行った。

\section{2-2 皮膜組成の分析}

皮膜中のすず及びりん含量の分析は予め作成した検量 線を用いてけい光X線分析法で行った。

\section{2-3 腐食試験}

2-3-1 浸せき試験による自然溶解量の測定

膜厚約 $40 \mu \mathrm{m}$ のすず含量の異なる各めっき皮膜につい

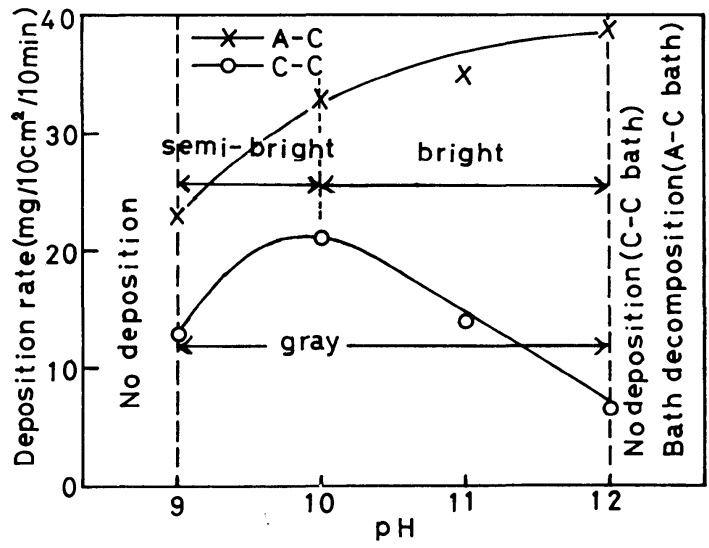

Fig. 1 Deposition rate vs. pH

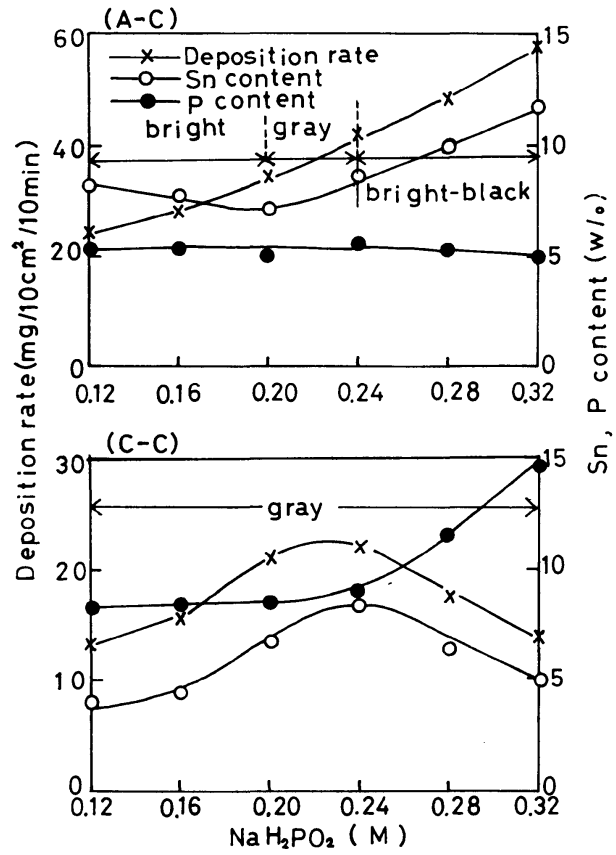

Fig. 2 Effect of conentration of $\mathrm{NaH}_{2} \mathrm{PO}_{2}$ on the deposition rate and $\mathrm{Sn}$ or $\mathrm{P}$ content
て $0.5 \mathrm{M}$ 硫酸溶液 $\left(30^{\circ} \mathrm{C}\right)$ 中に特ける自然溶解量の経時 変化を測定し，溶解量よりファラデーの法則から溶解時 の腐食電流密度を求めて皮膜の溶解性を比較した。

\section{2-3-2 外部分極曲線の測定}

外部分極曲線はポテンシオスタットを用いて $125 \mathrm{mV}$ /min の電位走査速度で分極し, 電流を対数変換後, X Y レコーダで自動記録して求めた。電解液は $30^{\circ} \mathrm{C} の 0.5 \mathrm{M}$ 硫酸溶液を使用し, 膜厚約 $40 \mu \mathrm{m}$ の試片を $1 \mathrm{~cm} \times 1 \mathrm{~cm}$ 残してフロンマスクでお拗た。参照電極には飽和力口 メル電極を使用した。試片を設置した後30分間窒素ガス で脱気後，分極曲線を得た。得られたカソード，アノー ド外部分極曲線からターフェル線を描き，腐食電流密度 及び腐食電位を求めた。

\section{2-4 X 線回折曲線の測定}

$\operatorname{CoK} \alpha$ 線を用いて各皮膜の $\mathrm{X}$ 線回折曲線を求め，皮膜 物質の同定及びその半価值からシェラー式により結晶粒 子径の值を概算した。

\section{3. 実験結果及び考案}

\section{3-1 好適浴組成及び条件の決定}

\section{3-1-1 pH変化による影響}

表 1 に示した基本浴条件下で $\mathrm{pH}$ を変化したときの影 響を調べた結果は図 1 に示すようにA-C浴，C-C浴と も $\mathrm{pH} 9$ 以下ではめっきは析出しなかった。 $\mathrm{A}-\mathrm{C}$ 浴では $\mathrm{pH}$ の増加に伴い析出速度は増加した。しかし $\mathrm{pH} 12$ 以上 では浴は不安定となった。表面状態は $\mathrm{pH}$ の低いところ では半光沢で， $\mathrm{pH}$ の上昇とともに光沢性のある良好な

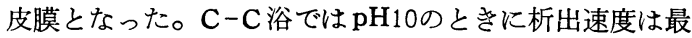
高值を示し, さらに $\mathrm{pH}$ が増加すると析出速度は減少し た。析出速度の減少はニッケルークエン酸錯体がより安 定度を増すためと考えられる。表面状態はいずれの $\mathrm{pH}$ に拈いてもすべて灰白色であった。以上の結果より，析 出速度, 表面状態から見て $\mathrm{A}-\mathrm{C}$ 浴では $\mathrm{pH} 11, \mathrm{C}-\mathrm{C}$ 浴 では $\mathrm{pH} 10$ が好適条件と思われる。

\section{3-1-2 $\quad \mathrm{NaH}_{2} \mathrm{PO}_{2}$ 濃度の影響}

次に基本浴条件下でA-C 浴の $\mathrm{pH}$ を11, C-C浴の $\mathrm{pH}$ を10と一定して次要りん酸塩濃度を0.12Mから0.32Mま で変化させたときのめっき速度及び析出皮膜組成の分析 結果を図 2 に示した。A-C浴では次亜りん酸ナトリウ ム濃度の増加に伴い, 析出速度は直線的に増加した。一 方すず含量は次覀りん酸ナトリウム濃度 $0.2 \mathrm{M}$ まではほ ぼ7\%から $8 \%$ と一定で，さらに濃度が増加するとすず 含量は $12 \%$ まで増加した。りん含量はほぼ5\%と一定で あった。表面状態は次亜りん酸ナトリウム濃度が $0.2 \mathrm{M}$ まで光沢性であるが，0.20Mから0.24Mで灰白色，0.24 M以上で黒色を示した。以上の結果より次亜りん酸ナト リウム濃度は特に表面状態の面から $0.2 \mathrm{M}$ 以下が好適と 思われる。次にC-C浴では次亜りん酸濃度が $0.24 \mathrm{M} て ゙$ 
析出速度は最高值を示 す。0.24Mまでは還元力 が増し，これ以上になる と浴が不安定となり析出 速度が減少するものと考 えられる。すず含量は析 出速度の変化と類似の傾 向を示し，0.24Mで最高 值 $8.5 \%$ であった。りん 含量は次亜りん酸ナトリ ウム濃度が0.24Mまでは

Table 2 Bath compositions and plating conditions (A-C)

\begin{tabular}{c|c|c|c|c|c}
\hline $\mathrm{M}^{\text {Bath } \mathrm{N}_{0}}$ & 1 & 2 & 3 & 4 & 5 \\
\hline $\mathrm{NiCl}_{2}$ & 0.1 & 0.1 & 0.1 & 0.1 & 0.1 \\
\hline $\mathrm{NaH}_{2} \mathrm{PO}_{2}$ & 0.2 & 0.2 & 0.2 & 0.2 & 0.2 \\
\hline $\mathrm{Na}_{2} \mathrm{SnO}_{2}$ & 0.000 & 0.002 & 0.004 & 0.006 & 0.010 \\
\hline $\mathrm{Na}^{-} \mathrm{Cit}$ & 0.12 & 0.12 & 0.12 & 0.12 & 0.12 \\
\hline $\begin{array}{c}11 \\
\text { temp. }\end{array}$ & $\begin{array}{c}110^{\circ} \mathrm{C} \pm 1 \mathrm{NH}_{4} \mathrm{C} \\
0 \mathrm{OH}\end{array}$ \\
\hline \hline
\end{tabular}

$(\mathrm{C}-\mathrm{C})$

\begin{tabular}{l|c|c|c|c}
\hline \hline Bath No. & 1 & 2 & 3 & 4 \\
\hline $\mathrm{NiCl}_{2}$ & 0.1 & 0.1 & 0.1 & 0.1 \\
\hline $\mathrm{NaH}_{2} \mathrm{PO}_{2}$ & 0.24 & 0.24 & 0.24 & 0.24 \\
\hline $\mathrm{Na}_{2} \mathrm{SnO}_{2}$ & 0.000 & 0.002 & 0.003 & 0.005 \\
\hline $\mathrm{Na}^{-\mathrm{Cit}}$ & 0.12 & 0.12 & 0.12 & 0.12 \\
\hline $\begin{array}{c}10 \mathrm{wH} \\
\text { temp. }\end{array}$ & \multicolumn{4}{|c}{$90^{\circ} \mathrm{C} \pm 1{ }^{\circ} \mathrm{C}$} \\
\hline
\end{tabular}

ほぼ9\%と一定で，さらに増加するとりん含量も15\%ま で増加した。表面状態はすべて灰白色であった。以上の 結果より，析出速度が大きくすず含量の多い皮膜を得る ため, 次亜りん酸ナトリウム濃度は0.24M付近が好適と 思われる。

\section{3-1-3 $\quad \mathrm{Na}_{2} \mathrm{SnO}_{2}$ 濃度の影響}

以上の検討結果から表 2 に示す好適浴条件を決定し た。この条件下で A-C 浴で亜すず酸ナトリウム濃度を 0から0.01Mまで, C-C浴では0から0.005Mまで変化 させたときの析出速度, 析出皮膜組成及び表面状態に及 ぼす影響を調べその結果を図 3 に示した。図からわかる ようにA-C 浴では亜すず酸ナトリウム濃度0.004Mまで は析出速度は $35 \mathrm{mg} / 10 \mathrm{~cm}^{2} ・ 10 \mathrm{~min}$ とほぼ一定であるが， それ以上では $80 \mathrm{mg} / 10 \mathrm{~cm}^{2} ・ 10 \mathrm{~min}$ まで急激に増加す る。一方,すず含量は $0 \%$ から19\%まで増加した。また, りん含量は $3 \%$ \% $5 \%$ とあまり変らなかった。表面状 態は要すず酸ナトリウム濃度が $0.004 \mathrm{M}$ 以下で光沢めっ きであるが，0.004Mから0.006Mで黒色，0.006 M 以上 で黒色光沢めっきとなった。次に $\mathrm{C}-\mathrm{C}$ 浴の場合には覀 すず酸ナトリウム濃度 $0.003 \mathrm{M}$ のとさに析出速度は最高

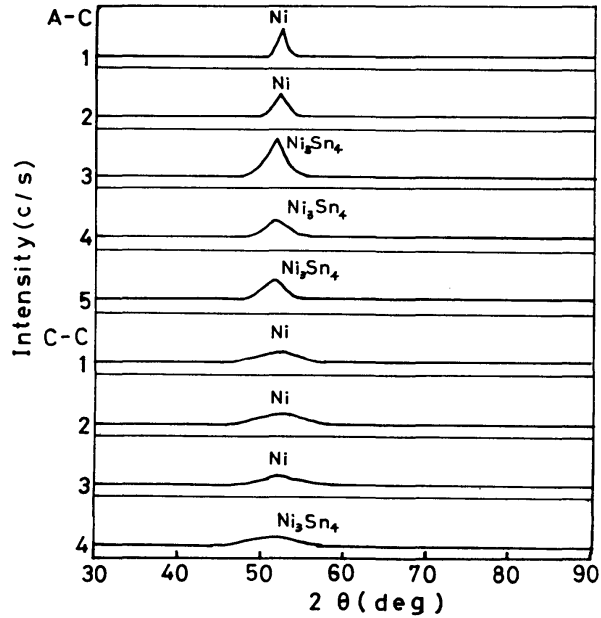

Fig. $4 \mathrm{X}$-ray diffraction curves for each deposited films ; target $\mathrm{Co}$, filter $\mathrm{Fe}$

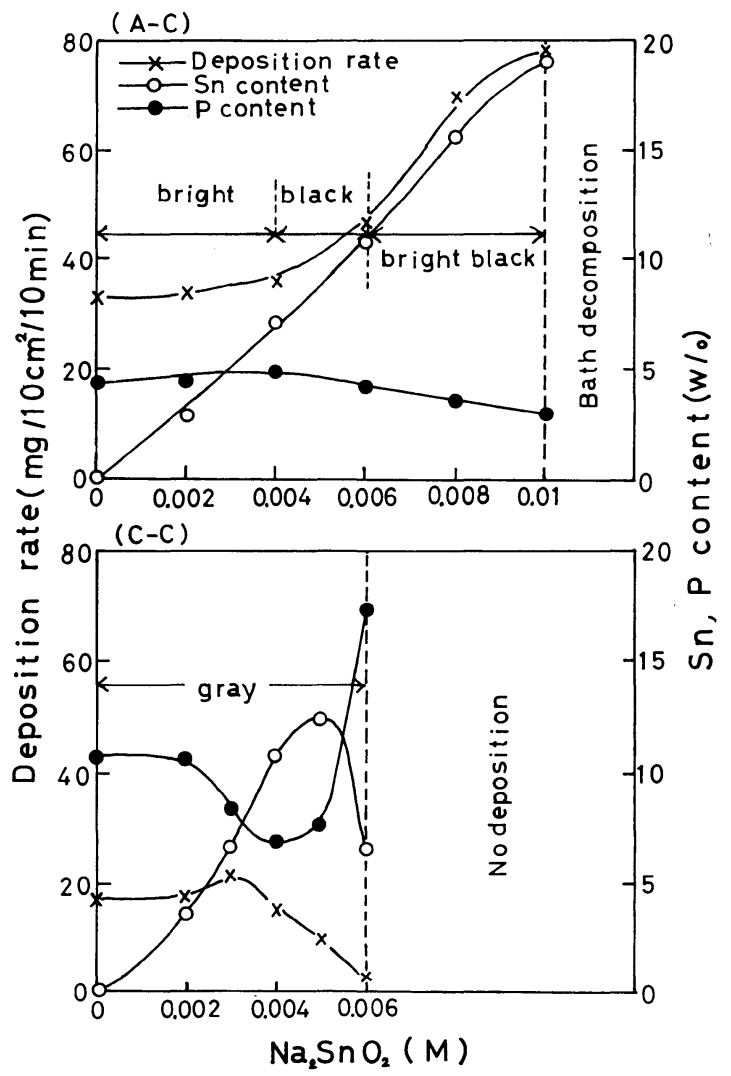

Fig. 3 Effect of concentration of $\mathrm{Na}_{2} \mathrm{SnO}_{2}$ on the deposition rate and $\mathrm{Sn}$ or $\mathrm{P}$ content

值を示し,さらに増すと析出速度は減少していき, 0.006 Mではほとんど析出は起こらなかった。これはめっき皮 膜中にすずが含有されるとめっき反応の触媒毒としてす ずが作用し析出速度を減少させるものと思われる。すず 含量は 0.005M で最高值12.4\%を示した。りん含量は亜 すず酸ナトリウム濃度の增加に伴って $10.8 \%$ から $7.7 \%$ と減少し，すず含量と逆の傾向を示した。表面状態はす ベて灰白色であった。

\section{3-2 X 線回折曲線}

$\mathrm{A}-\mathrm{C}$ 浴， C-C浴において亜すず酸ナトリウム濃度を 
変化させて得たすず含量の異なる各皮膜の X線回折曲線 を図 4 に示した。図からわかるように A-C 浴からの皮 膜はX線的に微結晶質であるが， C-C 浴からの皮膜は すべてブロードパターンを示しX線的に非晶質で粒子は 小さくなっている。次に回折曲線から測定した回折角を 表 3 に示して析出物を同定し，さらに半価值を測定しシ ェラー式から結晶粒子径を求め併せて表 3 にまとめた。 その結果， A-C 浴と C-C 浴とを比較すると C-C 浴の 方が粒子径が小さいのは C-C 浴からの皮膜にはりん含 量が $8 \%$ から $11 \%$ と A-C浴からの皮膜の 3\%から $5 \%$ にくらべて多く含まれるため粒子径がより小さくなって

Table 3 Diffraction angle, materials, half width and particle sizes

\begin{tabular}{r|c|c|c|c}
\hline $\begin{array}{c}\text { sample } \\
\text { No. }\end{array}$ & $\begin{array}{c}\text { Diffraction } \\
\text { angle }: 2 \theta \\
(\mathrm{deg})\end{array}$ & Material & $\begin{array}{c}\text { Half width } \\
\text { (radian) } \times 10^{2}\end{array}$ & $\begin{array}{c}\text { Particle } \\
\text { size }(\AA)\end{array}$ \\
\hline A-C 1 & 52.2 & $\mathrm{Ni}$ & 2.09 & 86 \\
\hline 2 & 52.0 & $\mathrm{Ni}$ & 2.44 & 73 \\
\hline 3 & 51.4 & $\mathrm{Ni}_{3} \mathrm{Sn}_{4}$ & 2.62 & 68 \\
\hline 4 & 51.4 & $\mathrm{Ni}_{3} \mathrm{Sn}_{4}$ & 4.89 & 37 \\
\hline 5 & 51.5 & $\mathrm{Ni3} \mathrm{Sn}_{4}$ & 4.54 & 39 \\
\hline $\mathrm{C}-\mathrm{C} 1$ & 52.2 & $\mathrm{Ni}$ & 11.9 & 15 \\
\hline 2 & 52.0 & $\mathrm{Ni}$ & 12.9 & 14 \\
\hline 3 & 51.9 & $\mathrm{Ni}$ & 13.6 & 13 \\
\hline 4 & 51.5 & $\mathrm{Ni} 3 \mathrm{Sn}_{4}$ & 12.2 & 14 \\
\hline \hline
\end{tabular}

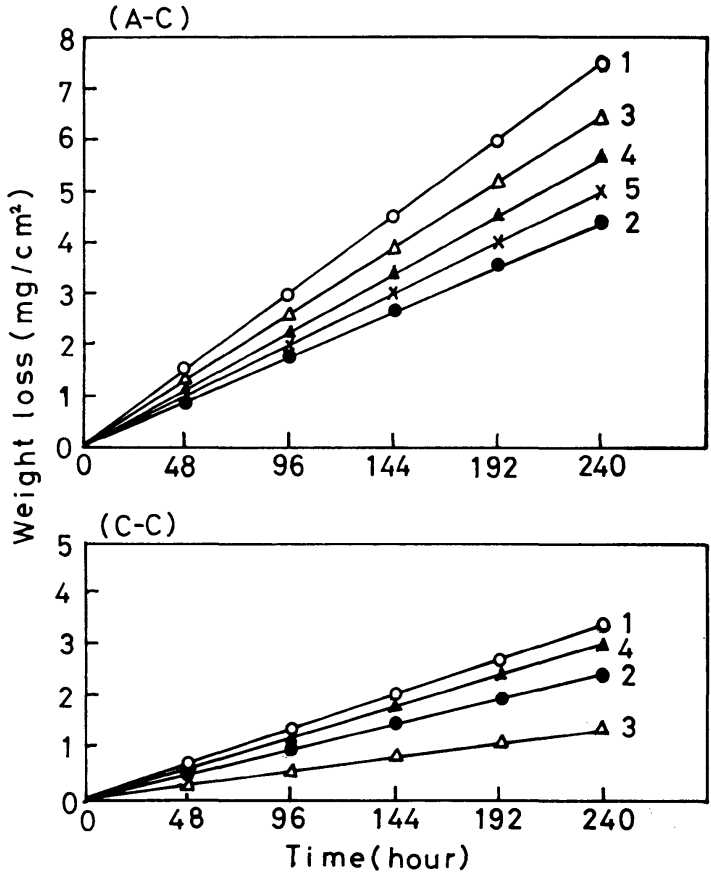

Fig. 5 Weight loss-immersion time curves for each deposited films
いるものと考えられる。

$\mathrm{A}-\mathrm{C}$ 浴からの皮膜では 回折角はすず含量の增加に伴 って, ニッケルの回折角 $2 \theta=52.2$ から低角度側にシフ トしていき，すず含量約 $7 \%$ から19\%の試料 3，4，5で $2 \theta=51.4$ ～51.5の回折線があらわれ，これは $\mathrm{Ni}_{3} \mathrm{Sn}_{4}$ に 一致している。したがって皮膜中のすず含量が增加する と，すずは $\mathrm{Ni}_{3} \mathrm{Sn}_{4}$ と思われる化合物として析出してい るものと考光られる。そして粒子径はすず含量の增加と ともに小さくなっている。C-C浴からのものでも回折 角はすず含量の増加に伴って低角度側にシフトしてすず 含量約 $12 \%$ の試料 4 で $2 \theta=51.5$ の $\mathrm{Ni}_{3} \mathrm{Sn}_{4}$ の析出がある ものと思われる。しかし粒子径にはあまり差は認められ ない。

\section{3-3＼cjkstart浸せき試験による腐食特性}

各皮膜を $0.5 \mathrm{M}$ 硫酸溶液 $\left(30^{\circ} \mathrm{C}\right)$ 中に浸せきし，その 時間に対する腐食溶解量との関係を図 5 に示した。図か らわかるようにA-C浴からの皮膜と C-C 浴からのもの とを比較すると全般に C-C 浴からの皮膜の方が耐食性 が良い。これは C-C浴からの皮膜の方がりん含量が多 く，粒子が小さくなったためにそのような影響が現われ たものと思われる。次に $\mathbf{A}-\mathbf{C}$ 浴から皮膜では試料 1, 3, 4，5，2 の順に溶けにくい。試料 3，4，5はすず含量が 7. $2 \%$ から $19.2 \%$ とすず含量2,8\%の試料に比べて多いに もかかわらす溶けやすくなっているのは，これは試料3， 4，5 9皮膜中にX線回折から推定された金属間化合物 $\left(\mathrm{Ni}_{3} \mathrm{Sn}_{4}\right)$ が析出し, この疑安定相の $\mathrm{Ni}_{3} \mathrm{Sn}_{4}$ は $\mathrm{NiSn}$ よ りも耐食性に扣いて非常に劣っているため6)，溶けやす くなったものと考えられる。そして $\mathrm{Ni}_{3} \mathrm{Sn}_{4}$ が析出した 場合, 粒子径が小さい注ど溶けにくい傾向にある。C-C 浴からの皮膜では試料 $1 ， 4 ， 2 ， 3$ の順に溶けにくくな っている。すず12. $4 \%$ を含有する試料 4 もめっき皮膜中 に $\mathrm{Ni}_{3} \mathrm{Sn}_{4}$ が存在し，その上りん含量も少ないため試料2, 3 のすず含量3.6〜8.4\%の皮膜より溶解しやすくなった ものと思われる。試料 1，2，3に打いてはすず含量が増 加するにしたがって溶けにくくなっていた。A-C 浴, $\mathrm{C}-\mathrm{C}$ 浴とも皮膜中に $\mathrm{Ni}_{3} \mathrm{Sn}_{4}$ が析出しない場合，すず含 量の增加に伴い耐食性が良好となることがわかった。以 上の結果, 溶解特性も粒子径, 皮膜組成から関連づける と， $\mathrm{A}-\mathrm{C}$ 浴， $\mathrm{C}-\mathrm{C}$ 浴とも皮膜中のすず含量が增加する と粒子径は小さくなり溶解しにくくなる。また C-C浴 からの皮膜のように粒子径の小さいほど溶けにくい。し かしA-C浴ですず含量約 $7 \%$ 以上， C-C浴ですず含量 約 $12 \%$ 以上では $\mathrm{Ni}_{3} \mathrm{Sn}_{4}$ と思われる化合物が析出すると, 皮膜はかえって溶けやすくなり，そのときは粒子径が大 きいほど溶けやすい傾向がある。

\section{3-4 外部分㮒曲線}

図6に各浴から得られたすず含量，りん含量の異なる ニッケルーすずーりん合金めっき皮膜の外部分極曲線を 
示した。図からわかるように $\mathrm{A}-\mathrm{C}$ 浴 ではカソード分極 曲線に扣いて，一0.3Vからー0.6Vの範囲において試料 $3 ， 4 ， 5 ， 2 ， 1$ の順に水素過電圧は大きくなっている。 試料 3，4，5 に拈いて試料 1，2 上り水素発生が多いの は，めっき皮膜中に金属間化合物が析出して表面状態が 粗になっているためと思われる。一方，アノード分極曲 線において，すべて不動態は形成されず，最も溶けにく い試料 2 でー0.1 Vから0.2Vの範囲で電流密度が一定と なる疑似不動態があらわれている。 C-C 浴ではカソー ド分極曲線に拈いてー0.4Vからー0.7Vの範囲では水素 過電圧は試料 4，3，2，1 の順に大きくなっていた。

ここですず含量 $0 \%$ の試料 1 の水素過電圧が小さくな っているのはりん含量が多いためと思われる。アノード 分極曲線ではすべての試料でー0.1Vから0.2Vの範囲に おいて A-C 浴の試料 2 のごとき疑似不動態の挙動を示 し，その電流密度は溶けにくい皮膜ほど小さくなってい る。

\section{3-5 腐食電流密度と腐食電位}

浸せき試験から自然溶解量を測定しファラデー則から 求めた腐食電流密度と外部分極曲線からターフェル線を 描き求めた腐食電流密度と腐食電位の值を表 4 に示し た。

表からわかるように A-C 浴, C-C 浴両浴からの皮膜 の溶解量から求めた腐食電流密度とターフェル線から求 めたものと必ずしも一致しないがその值は傾向は一致し ている。そして溶けにくい皮膜ほど腐食霓流密度は小さ く，腐食電位は貴となっていた。

\section{4. 結 言}

以上の実験結果より亜すず酸ナトリウム添加浴からの 無電解ニッケルーすずーりん合金めっきについて次のこと が明らかとなった。

（1）めっき浴に添加する亜すず酸ナトリウム濃度変化 による析出速度はアンモニアアルカリ性クエン酸浴 (A-C浴)とカセイアルカリ性クエン酸浴 $(\mathrm{C}-\mathrm{C}$ 浴) と は異なっており，A-C浴では亜すず酸ナトリウム濃 度の増加で析出速度は大きくなるが， C-C 浴ではあ まり変化はない。

（2）皮膜中のすず含量は A-C 浴から最高 $19.2 \%, \mathrm{C}$ C 浴からは12.4\%の皮膜を得ることができた。

（3）皮膜の $0.5 \mathrm{M}$ 硫酸 $\left(30^{\circ} \mathrm{C}\right)$ に対する溶解特性はAC 浴ではすず含量 $2.8 \%$, りん含量 $4.4 \%$ の皮膜, CC浴ではすず含量8.4\%，りん含量8.3\%の皮膜が最も 溶けにくいことがわかった。

（4）溶解特性をX 線回折からの結果と関連づけると, 両浴ともすずが皮膜中に含有すると溶けにくくなる。

(5) しかしA-C浴ですず含量約 $7 \%$ 以上で $\mathrm{Ni}_{3} \mathrm{Sn}_{4}$ が析

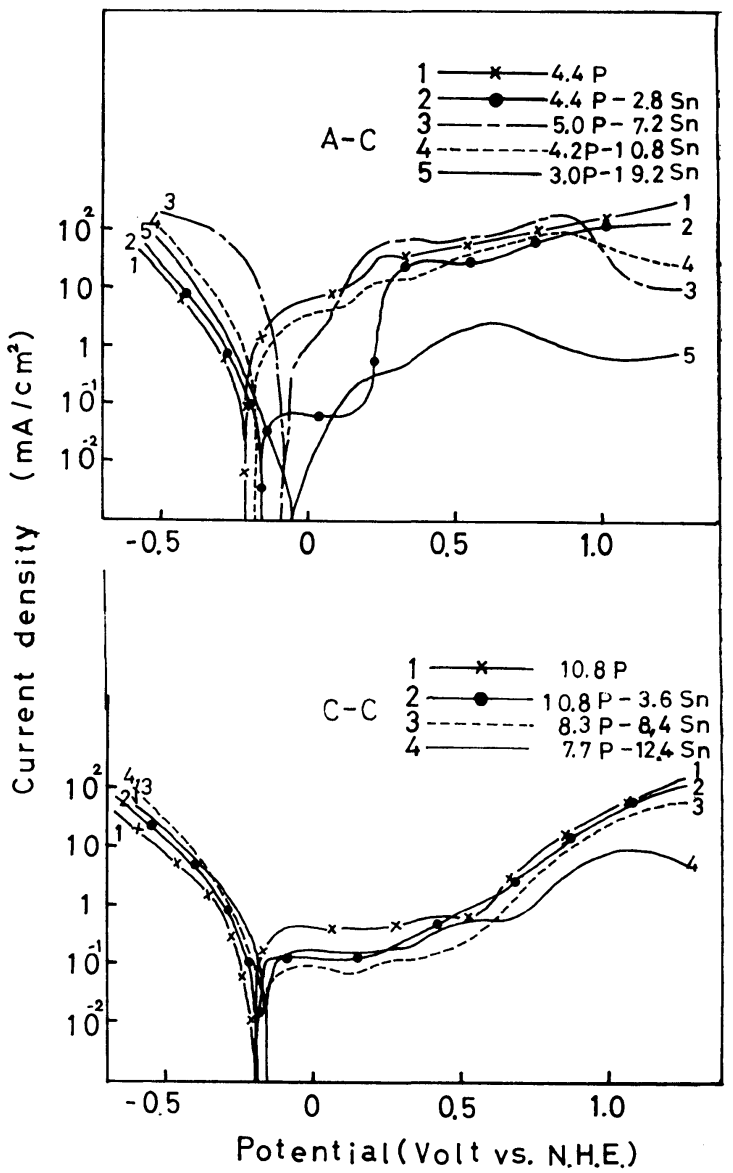

Fig. 6 Anodic and cathodic polarization curves for each deposited films.

Table 4 Corrosion current densities and corrosion potentials

\begin{tabular}{|c|c|c|c|}
\hline & (From weight loss) & \multicolumn{2}{|c|}{ (From Tafel's line) } \\
\hline $\begin{array}{l}\text { sample } \\
\text { No. }\end{array}$ & $\begin{array}{l}\text { Corrosion current } \\
\text { density }\left(\mu \mathrm{A} / \mathrm{cm}^{2}\right)\end{array}$ & $\begin{array}{l}\text { Corrosion current } \\
\text { density }\left(\mu \mathrm{A}, \mathrm{cm}^{2}\right)\end{array}$ & $\begin{array}{l}\text { Corrosion potential } \\
\qquad(\mathrm{mV})\end{array}$ \\
\hline$A-C 1$ & 28.9 & 180 & -180 \\
\hline 2 & 17.3 & 2 & 170 \\
\hline 3 & 25.0 & 100 & -50 \\
\hline 4 & 22.0 & 40 & 0 \\
\hline 5 & 19.3 & 14 & 10 \\
\hline C- $\mathrm{C} 1$ & 13.0 & 40 & 10 \\
\hline 2 & 9.6 & 10 & 70 \\
\hline 3 & 5.4 & 8 & 100 \\
\hline 4 & 11.9 & 23 & 30 \\
\hline
\end{tabular}

出し溶けやすくなり，またその粒子径が大きい汪ど溶 けやすい。C-C浴ではすず含量約 $12 \%$ 以上で $\mathrm{Ni}_{3} \mathrm{Sn}_{4}$ が析出し,やはり溶解しやすくなる。(1980-6-30 受理) （昭和52年 5 月，本協会第55回講演大会にて講演発表） 
本論文の非 S I 単位の S I 単位に対する換算表

\begin{tabular}{|c|c|c|}
\hline 量 & 単位記 号 & S I 単位による値 \\
\hline 速 & $\begin{array}{l}\mathrm{mg} / 10 \mathrm{~cm}^{2} \\
10 \mathrm{~min}\end{array}$ & $\begin{array}{l}1 \mathrm{mg} / 10 \mathrm{~cm}^{2} \cdot 10 \mathrm{~min} \\
=1.7 \times 10^{-5} \mathrm{~kg} / \mathrm{m}^{2} \cdot \mathrm{s}\end{array}$ \\
\hline \multirow[t]{2}{*}{ 電流密度 } & $\mathrm{mA} / \mathrm{em}^{2}$ & $1 \mathrm{~mA} / \mathrm{cm}^{2}=10 \mathrm{~A} / \mathrm{cm}^{2}$ \\
\hline & $\mu \mathrm{A} / \mathrm{cm}^{2}$ & $1 \mu \mathrm{A} / \mathrm{cm}^{2}=1 \times 10^{-2} \mathrm{~A} / \mathrm{cm}^{2}$ \\
\hline 質量／面積 & $\mathrm{mg} / \mathrm{cm}^{2}$ & $1 \mathrm{mg} / \mathrm{cm}^{2}=1 \times 10^{-2} \mathrm{~kg} / \mathrm{m}^{2}$ \\
\hline 体積／面積 & $200 \mathrm{~cm}^{2} / 10 \mathrm{~cm}^{2}$ & $\begin{array}{l}200 \mathrm{~cm}^{2} / 10 \mathrm{~cm}^{2} \\
=2 \times 10^{-1} \mathrm{~m}^{3} / \mathrm{m}^{2}\end{array}$ \\
\hline 長 & $\AA$ & $1 \AA=1 \times 10^{-10} \mathrm{~m}$ \\
\hline 濃 & M & $1 \mathrm{M}=1 \mathrm{~mol} / l$ \\
\hline
\end{tabular}

\section{文献}

1）榎本英彦，中川融；ピロリン酸浴によるスズーニッ ケル合金めっき，本誌，27，569（1976）

2) J. E. Bennet and H. G. Tompkins ; Investigation of an Electrodeposited Tin-Nickel Aolly, (I. Thermal Stability by Differential Thermal Analysis and X-Ray Diffraction) J. Electrochem. Soc., 123, 999 (1976)

3) В.Н. АНТИПОВ ; ПОЛУЧЕНИЕ СПЛАВА НИКЕЛБ-ОЛОВО МЕТОДОМ ХИМЕЧЕСКОГО ВОССТАНОВЛЕНИЯ, 3 АЩИТА МЕГАЛЛОВ 5, 210 (1973)

4）青木公二, 鷹野修, 石橋知, 林忠夫；アンモニアア ルカリ性浴からの無電解ニッケルースズーリン合金めっ きについて，本誌，28，629（1977）

5）青木公二, 鷹野修，石橋知，林忠夫；酸性浴からの 無電解ニッケルースズーリン合金めっきについて，本 誌, 29, 16 (1978)

6）青谷薰；合金めっき p. 63（1970 梖書店）

\section{本協会刊行物案内}

○第54回学衍講演大会要旨集 (昭和51年)

1 冊 1,500 円 (発送手数料 300円)

○第55回学術講演大会要旨集 (昭和52年)

1 冊 1,500 円 (発送手数料 300 円)

○第56回学術講演大会要旨集（昭和52年）

1 冊 2,000円 (送料込子)

○第58回学術講演大会要旨集 (昭和53年)

1 冊 2,000円（送料込2）（会員外3,000円）

○第59回学術講演大会要旨集 (昭和54年)

1 冊 2,000円 (送料込及)

（会員外3,000円）

○第61回学術講演大会要旨集 (昭和55年)

1 冊 2,000円 (送料込み)

（会員外3,000円）

○メッキ技術資料集(3)「合金メッキおよび複合メッキ」

1 冊 6,500円 (発送手数料 200 円)

○メッキ技術資料集(4)「工業用めっき」

1 冊 7,500 円 (発送手数料 500 円)

○メッキ技術資料集(5)「無公害めっき拉よび排水処理」

1 冊 7,000 円 (発送手数料 500 円)
○第10回金属表面技術入門講座テキストNo. 1 No.7 （昭和52年10月）

各 1 冊 1,000円 (発送手数料 1 冊付付 200円)

○第 5 回サマーセミナーテキスト「これからのフルマイ

ト業界のあり方」

1 冊 2,000円（送料含む）

○第6 回サマーセミナーテキスト「アルマイトの話題を 追う」 1 冊 2,000円（送料含む）

○アルマイト電解着色への電気めっき技術の応用シンポ ジウム・テキスト（昭和53年 9 月）

1 冊 1,000 円 (発送手数料 200 円)

○硬い表面を作るセミナー・テキスト（昭和54年10月）

1 冊 2,000円 (発送手数料 200 円)

○電気めっき工場におけけるリサイクル化ハンドブック

1 冊 2,000 円 (送料 300 円) (会員外 3,000円)

〈申込方法〉 氏名，送付先及び因書名を明記のらえ，

現金書留にて本協会あて，お申し込み下さい。

<申込先＞（社）金属表面技術協会

テ101 東京都千代田区神田岩本町 2 番地 共同ビル 